\title{
The impact of social identity of brand on brand loyalty development
}

\author{
Zohreh Dehdashti $^{\mathrm{a}}$, Mehdi Jafarzadeh Kenari ${ }^{\mathbf{a}^{*}}$ and Alireza Bakhshizadeh ${ }^{\mathrm{b}}$
}

${ }^{a}$ Department of Management and Accounting, Allame Tabtabaee University,Tehran, Iran

${ }^{b}$ Department of Management, Tarbiat Modares University, Tehran, Iran

\begin{tabular}{l}
\hline A R T I C L E I N F O \\
\hline Article history: \\
Received December 1, 2011 \\
Received in Revised form \\
February, 14, 2011 \\
Accepted 24 March 2012 \\
Available online \\
March 25 2012 \\
\hline Keywords: \\
Brand identity \\
Brand loyalty \\
Brand trust \\
Dairy products
\end{tabular}

\section{Introduction}

Brand is one of the most important intangible assets in any industry especially among business units. According to Keller (2008), the most valuable asset of any firms is not their equipments or services but it is the brand of a firm, which builds the actual value on customers' minds. According to American marketing association (AMA), brand is the name, expression, symbol or combinations of all these items, which builds company's identity. Brand is a commitment and it tells us that we know this name and we trust to the name and building a mutual trust is the primary objective of creating a brand. According brand is symbol for uniting different assets (Matzler, 2008).

One of the most important responsibilities of brands is to create loyalty among existing customers. Existing customers are the primary sources of revenue and they could increase margin of safety for firms. The other responsibility of brand is to provide an appropriate identity for brand and makes it as a unique source for people.

* Corresponding author. Tel: +989362647628

E-mail addresses: m.j.kenari@gmail.com (M. Jafarzadeh Kenari)

(C) 2012 Growing Science Ltd. All rights reserved. doi: $10.5267 / \mathrm{j} . \mathrm{msl} .2012 .03 .020$ 
Kapferer (2008) believes having a unique identity makes a brand different from other brands and we may be able to rely on for offering products and services. There have been tremendous efforts on brand but brand identity has received little attention (Da Silveira et al., 2011). However, there is a common fact among all people that brand identity influences people to distinguish a product from another (Joachimsthaler \& Aaker, 2000; Keller, 2008).

On the contrary to customer trust which is associated with external parameters influencing organization, brand identity is an internal item impacting organizations (Burmann et al., 2009). Brand identity has attracted little attention among researchers and there is literally little evidence to see any relationship between brand loyalty and brand identity (He \& Li, 2010; Marin et al., 2009).

In this paper, we look at the relationship between brand loyalty, its identity on creating brand identity. Brand identities, perception received from brand and customer satisfaction are various issues discussed in this paper.

\section{Literature review}

\subsection{Brand identity}

Brand identity is a set of exclusive features of a brand in terms of motto, promise and opportunities provided for customers and could create a new identity or improving previous identities. We can say identity is one of the most important factors for stabilizing brand and could lead it towards new markets and products (Keller, 2003; Ghodeswar, 2008). A brand identity is considered effective when it is accompanied with customers' needs (Joachimsthaler \& Aaker, 2000).

In other words, brand identity is a long-term plan for attracting more customers (Aaker, 1996). A brand could create an exclusive identity for its products or services when it builds sustainable and related promises, which are believable (Ward et al., 1999). According to Silveira et al. (2011) brand identity is not fixed issue over time but it is relatively dynamic concept and must change over time based on environmental parameters as well as economical factors.

\subsection{Brand loyalty}

Brand loyalty has been extensively investigated over the past few decades (Dick \& Basu, 1994; Oliver, 1999; Harris \& Goode, 2004; Evanschitzky et al., 2006) and there are different definitions for brand loyalty but Oliver (1999) gives the best one. Based on Oliver, brand loyalty reflects a long-term commitment of customer for repurchasing and becoming a permanent service or product receiver. Brand loyalty can be defined as an aggressive attitude towards purchasing a particular product over long-term horizon. This attitude could lead people to purchase from a particular brand and this is the result of people's perception (Chaudhuri \& Holbrook, 2001).

Any loyalty to a business brand is the result of repeat purchase activity, which is resulted from a psychological decision. The activities associated with the repeated purchase of a product are not based on people's direct intention but it is more unintentional and it is a result of different issues including emotions, feeling, etc. In marketing issues, the concept of loyalty to brand comes along with other words such as repurchase, preference, commitment and allegiance (Sahin et al., 2011; Fournier \& Mick, 1999; Chiou \& Shen, 2006).

\section{Proposed model}

The proposed model of this paper builds a conceptual model for the relationship between brand identity and loyalty. Fig. 1 shows details of the proposed model of this paper. 


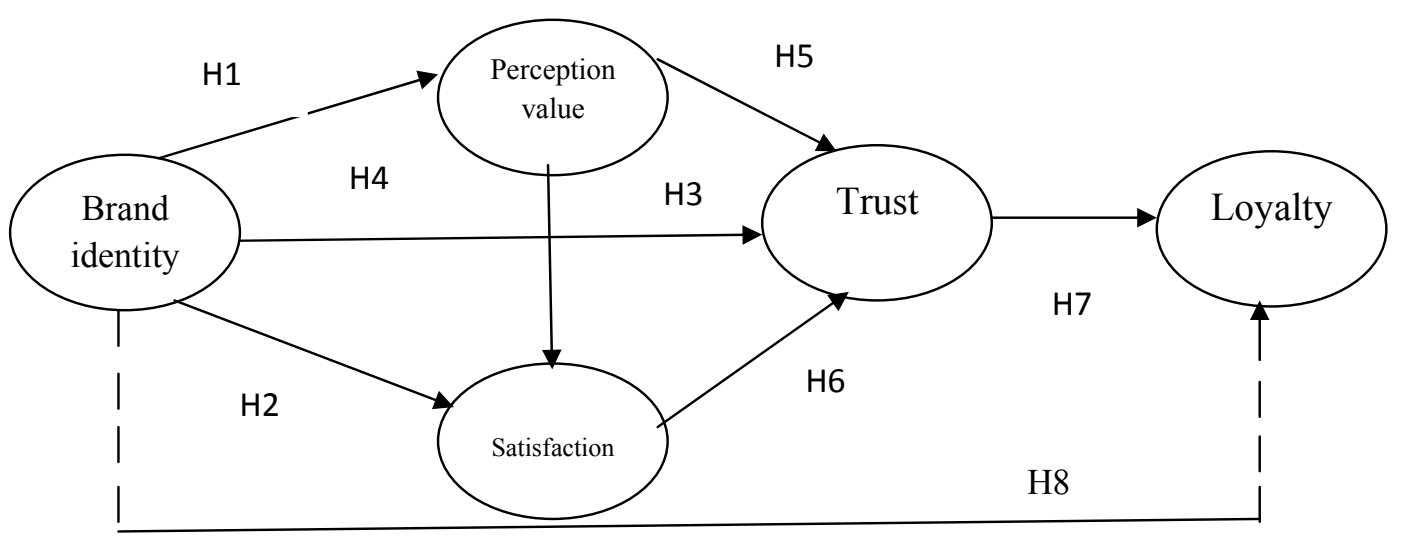

Fig. 1. The framework of the proposed model

\subsection{Brand identity and perception value}

There are different definitions associated with perception value such as the difference between revenue and cost (Khalifa, 2004), relationship between quality of different products sold under the same brand and the value of brand (Gabay, 2009). However, in marketing, perception value has two aspects of economical and non-economical (Ulaga, 2003; Woodside et al., 2008). Creating value is one of the most important subjects of research and many believe perception value is significantly influenced by brand identity (He et al., 2011). There are also some strong evidences, which indicate that a brand with strong identity has a better opportunity to increase perception value. (Parasuraman, et al., 1988). There are also other evidences, which show that there is positive relationship between brand and the value of brand (Hansen et al., 2008). There are eight hypotheses associated with the proposed study of this paper.

\subsection{Brand identity positively influences perception value}

Customer satisfaction is created from people's inside about how they are satisfied on received products or services (Bitner \& Hubbert, 1994). In other studies, customer satisfaction is a general customer's feeling on goods and services customers receive (Anderson et al., 2004). In many cases, a more prestigious and distinctive product could result on having stronger perception value (Bhattacharya \& Sen, 2008). People tend to be different from others and the more a brand is exclusive, the stronger it is and customer provide better support for it (He et al., 2011). A prestige brand is a particular brand, which is not only maintain a good quality but also it can be used for pretention.

\subsection{Brand identity and customer satisfaction}

There is a relationship between brand identity and customer satisfaction (He et al., 2011; Chun \& Davies, 2006). Therefore, we state the second hypothesis as follows,

H2: Brand identity has positive impact on customer satisfaction.

\subsection{Perception value and customer satisfaction}

The more a brand could attract more customers, the more customer satisfaction we have. There are different studies associated with these two concepts, which indicated a positive relationship between these two items (He et al., 2011; Harris \& Goode, 2004). 
H3: Perception value has a positive impact on customer satisfaction.

\subsection{Brand identity and trust}

Trust is the ability to rely or to accept an attribute associated with an object or a person. Trust to a brand is a psychological aspects, which reflects all assumptions hold on the reliability of a particular product or services (Doney \& Cannon, 1997). Trust on a brand is associated with credibility, integrity and benevolence (Gurviez \& Korchia, 2002; Simoes, 2005; Elliott \&Yannopoulou, 2007; Walsh et al., 2009). The following hypothesis is established for the proposed study of this paper.

H4: brand identity increases customers' trust.

\subsection{Perception value and trust}

As we have already explained, customer perception from brand value is a function of their perception and a particular brand has various values from different people's perspectives. There are different studies associated with perception value and trust (Parasuraman \& Grewal, 2000; Sirohi et al., 1998; Sweeney, et al., 1999). However, there are only a limited number of studies on relationship between perception value and supportive trust (Singh \& Sirdeshmukh, 2000, Harris \& Goode, 2004). Anderson and Srinivasan (2003) explained that perception and trust both could positively impact customer satisfaction and loyalty. Sirdeshmukh et al. (2002) performed an empirical study on the relationship between perception value and trust.

H5: Perception value from a brand influences on brand trust, positively.

\subsection{Customer satisfaction and trust}

There are literally many studies, which describes customer satisfaction is an emotional response to a purchase opportunity (Bagozzi et al., 1994; Anderson \& Narus, 1990; Bennet et al., 2005; Sahin et al., 2011). When a purchase yields a positive reaction, trust on brand is an immediate outcome. Trust, on the other hand, is the result of historical transaction. Trust on brand can be a result of advertisement, world of mouth advertisement and satisfaction from the purchase (Krishnan, 1996). It is relatively difficult to find a cause-and-effect relationship between customer satisfaction and trust. In other word, we cannot precisely say that customer satisfaction is the result of trust and trust is a function of customer satisfaction. He et al. (2011) confirmed the effect of customer satisfaction on trust and others considered the effects of trust on customer satisfaction (Harris \& Goode, 2004; Lam et al., 2004; Sichtmann, 2007; Sahin et al., 2011, Orth \& Green, 2009; Tsai, 2011).

H6: Customer satisfaction influences positively on brand trust.

\subsection{Trust and loyalty to brand}

Trust and loyalty have close relationship with each other. The more a customer trust to a particular brand, the more he/she will purchase that kind of product. Human being is naturally interested in reducing risk and this motivates many to become loyal to products and services. Trust can be defined as the degree of peace of mind where customer can rely on vendor (Agustin \& Singh, 2005). The more customer trusts a particular brand, the more customer become loyal to that brand (O'Shaughnessy, 1992). Therefore, a purchase happens without performing any cost/benefit analysis (Lau \& Lee, 1999). Therefore, building a brand yields a long-term relationship between customer and firm (Agustin \& Singh, 2005; Amine, 1998). Trust plays an important role in creating customer-brand relationship and has a positive impact on loyalty to brand (Sahin et al., 2011). Customer trust to a brand is a result of positive believes on organizational behavior expectations and performance of 
products (Ashley \& Leonard, 2009). Trust will increase customer loyalty and in long term loyal customer will be more loyal (Chiou \& Shen, 2006; Sweeney \& Swait, 2008; Ambler, 1997; Mazodier \& Merunka, 2011).

H7: Trust to a brand will positively influence on customer loyalty.

\subsection{Brand identity and loyalty}

As we have explained earlier, brand has relationship with three items of perception value, customer satisfaction and trust. We can explain that there is an indirect relationship between brand identity and on trust through three variables of perception value, customer satisfaction and trust.

H8: Brand identity indirectly has positive impact on customer loyalty through three variables of value, satisfaction and trust.

\section{Results}

The proposed study of this paper has designed a questionnaire and distributed among a randomly selected people who live in city of Tehran, the capital city of Iran. The proposed study was concentrated on a firm, which was one of major diary providers in Iran called Kalleh Diary Corporation.

\section{Table 1}

Statistical observations for the proposed study

\begin{tabular}{|c|c|c|c|}
\hline \multirow{2}{*}{\multicolumn{2}{|c|}{ Standardized factor loading }} & \multirow{2}{*}{$\begin{array}{c}\text { Cronbach alpha } \\
0.853\end{array}$} & \multirow{2}{*}{$\begin{array}{l}\text { AVE } \\
0.56\end{array}$} \\
\hline & & & \\
\hline This brand is superior to other brands. & 0.75 & & \\
\hline This is a high quality brand with high prestige level. & 0.68 & & \\
\hline This brand is very famous. & 0.75 & & \\
\hline This brand has an exclusive identity. & 0.84 & & \\
\hline Perception value of brand. & & 0.798 & 0.58 \\
\hline I am happy about what I paid and the value I gained. & 0.77 & & \\
\hline The products of this brand have been priced, properly. & 0.82 & & \\
\hline Based on what I received I pay relatively fair price. & 0.73 & & \\
\hline Customer satisfaction & & 0.853 & 0.65 \\
\hline I am completely satisfied from this brand. & 0.77 & & \\
\hline I am confident that I am always happy about the brand. & 0.84 & & \\
\hline I am happy about the products of this brand. & 0.81 & & \\
\hline I believe this brand could completely satisfy my expectations. & 0.77 & & \\
\hline Trust to brand & & 0.891 & 0.59 \\
\hline I trust to all brands' products. & 0.75 & & \\
\hline I have never had a bad experience on this brand. & 0.77 & & \\
\hline This brand has a nice image among people. & 0.79 & & \\
\hline If this brand claims a good feature, that would be true. & 0.73 & & \\
\hline This is an honest brand. & 0.79 & & \\
\hline Brand loyalty & & 0.865 & 0.54 \\
\hline This brand has exactly the same features as I wish. & 0.79 & & \\
\hline I prefer this brand to other ones. & 0.70 & & \\
\hline I have a negative attitude towards this brand. & 0.73 & & \\
\hline I like the features of this brand. & 0.78 & & \\
\hline This brand has a better performance compared with other brands. & 0.75 & & \\
\hline I always prefer this brand to other brands. & 0.55 & & \\
\hline I always wish to examine this brands' products. & 0.76 & & \\
\hline
\end{tabular}

We have randomly selected some grocery shopping centers, which were selling this brand's dairy products and have distributed some questionnaires among their customers, and collected 475 filled 
ones. All questions were designed based on Likert based scale from completely disagree to completely agree. All questions were selected based on a survey accomplished on relevant literature (He et al., 2011; Tong \& Hawley, 2009; Washburn et al., 2004; Allen \& Meyer, 1990; He et al., 2011; Tam, 2004). The reliability of all test components has been examined using both convergent and discriminate validity. Standardized factor loading as well as Average variance extracted were measured and they were well above 0.5, which is the minimum desirable level (Fornell \& Larker, 1981). Cronbach Alpha was calculated for all questions and they were well above 0.7, which is the minimum acceptable level (Nunnally, 1978). Table 2 shows correlation ratios among different components of our proposed study.

Table 2

Correlation ratios

\begin{tabular}{llllccl}
\hline & Value & Satisfaction & Trust & Loyalty & Brand identity & Mean \\
\hline Value & 1.00 & & & & & 3.14 \\
Satisfaction & 0.45 & 1.00 & & & 3.00 & 2.92 \\
Trust & 0.50 & 0.80 & 1.00 & & & 3.09 \\
Loyalty & 0.37 & 0.59 & 0.74 & 1.00 & & 3.10 \\
Brand identity & 0.62 & 0.74 & 0.73 & 0.54 & 1.00 & \\
\hline
\end{tabular}

We have performed goodness of fit for different tests and the results of our investigations are summarized in Table 3.

Table 3

Statistical test results for goodness of fit

\begin{tabular}{ccc}
\hline Attribute & Value & Acceptable region \\
\hline$\chi^{2}$ & 898.34 & \\
df & 412 & Less than 3 \\
$\chi^{2} / \mathrm{df}$ & 2.18 & Less than 0.1 \\
RMSEA & 0.041 & Greater than 0.9 \\
NFI & 0.98 & Greater than 0.9 \\
NNFI & 0.99 & Greater than 0.9 \\
CFI & 0.98 & Greater than 0.9 \\
IFI & 0.99 & Greater than 0.9 \\
GFI & 0.93 & Greater than 0.8 \\
\hline
\end{tabular}

In addition, Table 4 demonstrates the results of our test results on different hypotheses.

\section{Table 4}

The results of t-student tests

\begin{tabular}{lcccc}
\hline Hypothesis & $\mathrm{t}$-value & Path coefficient $(\beta)$ & $\left(\mathrm{r}^{2}\right)$ & Results \\
\hline The effect of identity on value & $12.51^{* *}$ & 0.62 & 0.44 & Confirmed \\
The effect of identity on satisfaction & $15.91^{* *}$ & 0.65 & 0.63 & Confirmed \\
The effect of value on satisfaction & $1.64^{* *}$ & 0.19 & 0.69 & Confirmed \\
The effect of identity on trust & $3.37^{* *}$ & 0.22 & 0.69 & Confirmed \\
The effect of value on trust & $1.95^{* *}$ & 0.097 & 0.69 & Confirmed \\
The effect of satisfaction on value & $9.61^{* *}$ & 0.60 & 0.69 & Confirmed \\
The effect of trust on loyalty & $14.66^{* *}$ & 0.74 & 0.62 & Confirmed \\
The effect of identity on loyalty & $13.01^{* *}$ & 0.54 & 0.33 & Confirmed \\
\hline${ }^{*} \mathrm{p}<0.05{ }^{* * *} \mathrm{p}<0.01$ & & & &
\end{tabular}

\subsection{First hypothesis}

As we can observe from the results of Table 4, t-student maintains a meaningful ratio for the test leading us to conclude that brand identity influences perception value. The path ratio shows that an increase of one unit in brand identity will increase perception value for 0.62 with the probability of 0.99. The ratio of $r^{2}$ shows that brand identity can describe 44 percent of perception value. 


\subsection{Second hypothesis}

As we can observe from the results of Table 4, t-student maintains a meaningful ratio for the test leading us to conclude that brand identity influences customer satisfaction. The path ratio also demonstrates that an increase of one unit in brand identity will increase customer satisfaction for 0.65 with the probability of 0.99 . The ratio of $r^{2}$ demonstrates that brand identity can describe 63 percent of customer satisfaction.

\subsection{Third hypothesis}

As we can observe from the results of Table 4, t-student maintains a meaningful ratio for the test leading us to conclude that perception value influences customer satisfaction. The path ratio also demonstrates that an increase of one unit in perception value will increase customer satisfaction for 0.19 with the probability of 0.99 . The ratio of $\mathrm{r}^{2}$ explains that perception value can describe 69 percent of customer satisfaction.

\subsection{Fourth hypothesis}

As we can observe from the results of Table 4, t-student maintains a meaningful ratio for the test leading us to conclude that brand identity influences brand trust. The path ratio also demonstrates that an increase of one unit in brand identity will increase brand trust for 0.62 with the probability of 0.99 . The ratio of $r^{2}$ we can understand that brand identity can describe 69 percent of brand trust.

\subsection{Fifth hypothesis}

As we can observe from the results of Table 4, t-student maintains a meaningful ratio for the test leading us to conclude that perception value influences brand trust. The path ratio also demonstrates that an increase of one unit in brand trust will increase perception value for 0.097 with the probability of 0.99 . From the ratio of $r^{2}$, we can understand that perception value can describe 69 percent of brand trust.

\subsection{Sixth hypothesis}

As we can observe from the results of Table 4, t-student maintains a meaningful ratio for the test leading us to conclude that customer satisfaction influences brand trust. The path ratio also demonstrates that an increase of one unit in brand trust will increase customer satisfaction for 0.60 with the probability of 0.99 . The ratio of $r^{2}$ implies that perception value can describe 69 percent of brand trust.

\subsection{Seventh hypothesis}

As we can observe from the results of Table 4, t-student maintains a meaningful ratio for the test leading us to conclude that brand trust influences customer loyalty. The path ratio also demonstrates that an increase of one unit in brand trust will increase customer loyalty for 0.74 with the probability of 0.99 . The ratio of $\mathrm{r}^{2}$ implies that trust value can describe 62 percent of brand loyalty.

\subsection{Eighth hypothesis}

As we can observe from the results of Table 4, t-student maintains a meaningful ratio for the test leading us to conclude that brand identity indirectly influences customer loyalty. The path ratio also demonstrates that an increase of one unit in brand identity will increase customer loyalty for 0.54 with the probability of 0.99 . The ratio of $r^{2}$ implies that brand identity can describe 33 percent of brand loyalty. 


\section{Conclusion}

In this study, we have considered the impact of brand identity on increasing product loyalty in one of Iranian dairy products. The proposed study has implemented in city of Tehran by choosing 475 people and it was analyzed using structural equation model and factor analysis. The results indicated that there was a direct positive relationship between brand and loyalty and a powerful brand could help setup a long-term relationship between customer and firm, which leads to brand loyalty. In other words, brand identity influences perception value, customer satisfaction, brand trust while perception value influences customer satisfaction and brand trust. In addition, customer satisfaction influences brand trust, brand trust influences customer loyalty and finally brand identity indirectly influences customer loyalty.

\section{References}

Aaker, D.A. (1996). Building Strong Brands. The Free Press, New York, NY, 35, 71.

Aaker, D.A. \& Joachimsthaler, E. (2000). Brand Leadership. The Free Press, New York, NY.

Agustin, C. \& Singh J. (2005). Curvilinear effects of consumer loyalty determinants in relational exchanges. Journal of Marketing Research, 42(1), 96-108.

Allen, N.J. \& Meyer, J.P. (1990). The measurement of and antecedents of affective, continuance, and normative commitment to the organization. Journal of Occupational Psychology, 63, 1-18.

Ambler, T. (1997). How much of brand equity is explained by trust?, Management Decision, 35(4), $283-292$.

Anderson, E.W., Fornell, C. \& Mazvancheryl, S.K. (2004). Customer satisfaction and shareholder value. Journal of Marketing, 68(4), 172-85.

Anderson C. J., \& Narus, A. J. (1990). A model of distributor firm and manufacturer firm working partnerships. Journal of Marketing, 54, 42-58.

Anderson, R. E., \& Srinivasan, S. S. (2003). E-satisfaction and E-loyalty: A contingency framework. Psychology and Marketing, 20(2), 99-121.

Ashley, C., \& Leonard, H. A. (2009). Betrayed by The Buzz? Covert content and consumer-brand relationships. Journal of Public Policy and Marketing, 28(2), 212-220.

Bagozzi, R. P., \& Todd F. H. (1994). A general approach to representing multifaceted personality constructs, Application to state self-esteem. Structural Equation Modeling, 1(1), 35-47.

Bennet, R., Hartel, C.J.H, \& Mccoll-Kennedy, J.R. (2005). Experience as a moderator of involvement and satisfaction on brand loyalty in a business-to-business settings. Industrial Marketing Management, 34, 97-107.

Bhattacharya, CB, \& Sen, S. (2003). Consumer-company identification: a framework for understanding consumers' relationships with companies. Journal of Marketing, 67(2), 76-88.

Bitner, M. J., \& Hubbert, A. R. (1994). Encounter satisfaction versus overall satisfaction versus quality. In R. T. Rust \& R. L. Oliver (Eds.). Service quality: New directions in theory and practice (72-94). London: Sage.

Burmann, C., Jost-Benz, M. \& Riley, N. (2009). Towards an identity-based brand equity model. Journal of Business Research, 62, 390-397.

Chaudhuri, A. \& Holbrook, B. M. (2001). The chain of effects from brand trust and brand affects to brand performance: The role of brand loyalty. Journal of Marketing, 65, 81-93.

Chiou, J.S., \& Shen, C.C. (2006). The effects of satisfaction, Opportunism, and asset specificity on consumers' loyalty intention toward internet portal sites. International Journal Service Industry Management, 17(1), 7-22.

Chun, R. \& Davies, G. (2006). The influence of corporate character on customers and employees: exploring similarities and differences. Journal of Academic Marketing Science, 34(2), 138-146.

Da Silveira, C., Lages, C. \& Simoes, C. (2011). Reconceptualizing brand identity in a dynamic environment. Journal of Business Research, doi:10.1016/ j.jbusres.2011.07.020. 
Dick, A., \& Basu, K. (1994). Customer loyalty: Toward an integrated conceptual framework. Journal of the Academy of Marketing Science, 22, 99-113.

Doney, P.M. \& Cannon, J.P. (1997). An examination of the nature of trust in buyer-seller relationships. Journal of Marking, 61(2), 35-51.

Elliott, R. \& Yannopoulou, N. (2007). The nature of trust in brands: a psychosocial model. European Journal of Marketing, 41(9/10), 988-998.

Evanschitzky, H., Gopalkrishnan, R. I., Plassmann, H., Niessing, J., \& Meffert, H. (2006). The relative strength of affective commitment in securing loyalty in service relationships. Journal of Business Research, 59, 1207-1213.

Fornell, C., \& Larcker, D. F. (1981). Evaluating structural equation models with unobservable variables and measurement error. Journal of Marketing Research, 18, 39-50.

Fournier, S. \& Mick Glen, D. (1999). Rediscounting satisfaction. Journal of Marketing, 63, 5-23.

Gabay, G., Moskowitz, H. R., Beckley, J. \& Ashman, H. (2009). Consumer centered "brand value" of foods: drivers and segmentation. Journal of Product \& Brand Management, 18(1), 4-16.

Ghodeswar, B. M. (2008). Building brand identity in competitive markets: a conceptual model. Journal of Product \& Brand Management, 17(1), 4-12.

Gurviez, P. and Korchia, M. (2002). Proposition d'unee'chelle de mesuremultidimensionnelle de la confiancedans la marquee. Rechercheet Applications en Marketing, 17(3), 41-59.

Harris, L. C., \& Goode, M. M. H. (2004). The four levels of loyalty and the pivotal role of trust: A study of online services dynamics. Journal of Retailing, 80, 139-158.

Hansen H., Samuelsen B.M., Silseth, P.R. (2008). Customer perceived value in B-2-B service relationships: investigating the importance of corporate reputation. Industrial Marketing Management, 37(2), 206-17.

He, H., Li, Y. \& Harris, L. (2011). Social identity perspective on brand loyalty. Journal of Business Research, doi:10.1016/j.jbusres.03.007.

He, H. \& Li, Y. (2010). CSR and service brand: the mediating effect of brand identification and moderating effect of service quality. Journal of Business Ethics, 100(4), 673-688.

Joachimsthaler, E. \& Aaker D. A. (1999). Building brands without mass media. Harvard Business Review on Brand Management, 1-22.

Kapferer, J-N. (2008). The new strategic brand management, creating and sustaining brand equity long term. London: Kogan Page

Keller, K.L. (2008). Strategic brand management, building, measuring and managing brand equity. Upper Saddle River, NJ: Prentice Hall.

Keller, K. L. (2008). Strategic Brand Management-Building, Measuring, and Managing Brand Equity. $3^{\text {rd }}$ ed., United States: PEARSON - Prentice Hall.

Keller, K. L. (2003). Understanding Brands, Branding and Brand Equity. Interactive Marketing, 5 (1), 7-20.

Keller, K.L. (2003) Strategic Brand Management: Building, Measuring and Managing Brand Equity. $2^{\text {nd }}$ ed., Prentice-Hall, Englewood Cliffs, NJ.

Khalifa, A.S. (2004). Customer value: a review of recent literature and an integrative configuration. Management Decision, 42(12), 645-66.

Krishnan, H. S. (1996). Characteristics of memory associations: a consumer-based brand equity perspective. International Journal of Research in Marketing, 13, 389-405.

Lam, S. Y., Venkatesh, S., Krishna Erramilli, M., \& Murthy, B. (2004). Customer value, satisfaction, loyalty, and switching costs: An illustration from a business-to-business service context. Journal of the Academy of Marketing Science, 32(3), 293-311.

Lau, G. T., \& Lee, S. H. (1999). Consumers' trust in a brand and the link to brand loyalty. Journal of Market Focused Management, 4, 341-370.

Lee, J. S. \& Back, K. J. (2008). Attendee-based brand equity. Tourism Management, 29, 331-344.

Marin, L., Ruiz, S., \& Rubio, A. (2009). The role of identity salience in the effects of corporate social responsibility on consumer behavior. Journal of Business Ethics, 84(1), 65-78. 
Matzler, K. (2008). Risk aversion and brand loyalty: the mediating role of brand trust and brand effect, 17(3), 154- 162 .

Mazodier, M. \& Merunka, D. (2011). Achieving brand loyalty through sponsorship: the role of fit and self-congruity. Academy of Marketing Science, DOI 10.1007/s11747-011-0285-y

Morgan, R.M. \& Hunt, S.D. (1994). The commitment-trust theory of relationship marketing? Journal of Marketing, 58(3), 20-38.

Nam, J., Ekinci, Y. \& Whyatt, G. (2011). Brand equity, brand loyalty and consumer satisfaction. Annals of Tourism Research, doi: 10.1016/j.annals.

Nunnally, J. C. (1978). Psychometric Theory. New York, NY: McGraw-Hill, Inc.

Oliver, R. L. (1999). Whence customer loyalty. Journal of Marketing, 63, 33-44.

O’Shaughnessy, J. (1992). Explaining Buyer Behavior. UK: Oxford University Press.

Orth, U. R. \& Green, M. T. (2009). Consumer loyalty to family versus non-family business: The roles of store image, trust and satisfaction. Journal of Retailing and Consumer Services, 16, 248-259.

Parasuraman, A., \& Grewal, D. (2000). The impact of technology on the quality-value-loyalty chain: A research agenda. Journal of the Academy of Marketing Science, 28(1). 168-174.

Sahin, A., Zehir, C. \& Kitapaci, H. (2011). The Effects of Brand Experiences, Trust and Satisfaction on Building Brand Loyalty; An Empirical Research On Global Brands. Procedia Social and Behavioral Sciences, 24, 1288-1301.

Sichtmann, C. (2007). Buyer-Seller relationships and the economics of information. Journal of Business Management, 1, 59-78.

Sichtmann, C. (2007). An analysis of antecedents and consequences of trust in a corporate brand. European Journal of Marketing, 41(9/10), 999-1015.

Simoes, C., Dibb, S. \& Fisk, P.R. (2005). Managing corporate identity: an internal perspective. Journal of Academic Marketing Science, 33(2), 153-168.

Singh, J., \& Sirdeshmukh, D. (2000). Agency and trust mechanisms in consumer satisfaction and loyalty judgments. Journal of the Academy of Marketing Science, 28(1), 150-168.

Sirdeshmukh, D., Singh, J., \& Sabol, B. (2002). Consumer trust, value, and loyalty in relational exchanges. Journal of Marketing, 66, 15-37.

Sirohi, N., McLaughlin, E. W., \& Wittink, D. R. (1998). A model of consumer perceptions an store loyalty intentions for a supermarket retailer. Journal of Retailing, 74(2), 223-245.

Sweeney, J. C., Soutar, G. N., \& Johnson, L. W. (1999). The role of perceived risk in the qualityvalue relationship: A study in a retail environment. Journal of Retailing, 75(1), 77-105.

Sweeney, J. \& Swait, J. (2008). The effects of brand credibility on customer loyalty. Journal of Retailing and Consumer Services 15, 179-193.

Tam, J.L.M. (2004). Customer satisfaction, service quality and perceived value: An integrative model. Journal of Marketing Management, 20(7/8), 897-917.

Tong, X. \& Hawley, J. M. (2009). Measuring customer-based brand equity: empirical evidence from the sportswear market in China. Journal of Product \& Brand Management, 18(4), 262-271.

Tsai, S-P. (2011). Fostering international brand loyalty through committed and attached relationships, International Business Review, 20(5), 5521-534.

Ulaga, W. (2003). Capturing value creation in business relationships: a customer perspective. Industrial Marketing Management, 23(8), 677-693.

Walsh, G., Mitchell, V.-W., Jackson, P.R. \& Beatty, S.E. (2009). Examining the antecedents and consequences of corporate reputation: a customer perspective. British Journal of Management, 20(2), 187-203.

Ward, S., Larry, L., \& Goldstine, J. (1999). What high-tech managers need to know about brands. Harvard Business Review, July-August, 85-95.

Washburn, J.H., Till, B.D., Priluck, R. (2004). Brand alliance and customer-based brand-equity effects. Psychology Marketing, 21(7), 487-508.

Woodside, A.G., Golfetto, F., \& Gibbert, M. (2008). Customer value: theory, research, and practice, in Woodside, A.G., Golfetto, F. and Gibbert, M. (Eds). Creating and Managing Superior Customer Value. Advances in Business Marketing and Purchasing, 14, 3-25. 